\title{
The role of leadership in the education system
}

\author{
Sefi Peleg \\ Universitatea Babeş-Bolyai, Cluj-Napoca
}

Email address:

sefip@013.net (S. Peleg)

\section{To cite this article:}

Sefi Peleg. The Role of Leadership in the Education System.. Education Journal. Vol. 1, No. 1, 2012, pp. 5-8.

doi: 10.11648/j.edu.20120101.12

\begin{abstract}
Educational leadership is a long-term campaign it grows out of knowledge, of experience and requires patience and much time, and its leadership can be enjoyed only in the long run. Who is leader? What is leadership? Definitions are abundant. Some claim there are 650 definitions, which is a clear sign of the lack of agreement. This article review the term "educational leadership" as it comes up in the recent approaches.
\end{abstract}

Keywords: Leadership, Management, Education, Schools, Teachers

\section{Introduction}

In today's world, we document almost everything we know.

These lists are often useful summaries of the knowledge we have, but not all provide us with enough inspiration or further our knowledge as we would wish. Furthermore, there are now so many lists on education and leadership to the point of needing a list of lists. What is the significance for school principals? And as regards policy makers?

Ben-Zvi (2003) claims that the objectives underlying educational leadership are raising the ability of those led to solve problems inspired by the leader, as well as building and encouraging those led to realize their potential, rise above mediocrity and move to high levels of performance and educational commitment.

Karmi (2004) avers that educational leadership in general and the teacher as an educational leader in particular, should develop learning materials, curricula, programs for change and effectiveness in class activities.

\section{Educational Leadership}

The definition of "Leadership" is associated predominantly with the army, but also with the economy and politics. Most of us hear the concepts of military leadership, economic leadership, national leadership or political leadership.

Kissinger, one of the greatest American statesmen, said that a leader's mission is to bring his people from the place where they are to a place where there have never been.

Therefor, leadership is necessary and relevant for educa- tion the same as it relevant in economy: "to bring his people from the place where they are to a place where there have never been".

Educational leadership is a long-term campaign it grows out of knowledge, of experience and requires patience and much time, and its leadership can be enjoyed only in the long run.

What it is known about educational leadership?

Throughout the world, the present period is the Golden Age of school leadership (Mulford, 2008: 1). In addition to the great interest in leadership governments and funds throughout the world invest in research and development this field. Training programs for school managers are now common. Many countries followed the way in which the National College for School Leadership (NCSL) in England developed and performed its mission. Other countries tried to go on its path and established a Leadership Institute or programs to train managers, or updated methods existing long before the Institute was founded. The empirical findings that accumulated are enough to persuade doubters of the importance of leadership (Day \& Leithwood, 2007:1).

The importance is expressed by Leithwood, Day, Sammons, Harris, \& Hopkins. (2006:4) that school leadership is of secondary importance to learning, after the quality of classroom teaching. Criticism of schools in England (Whelan, 2009: 78) shows that of every 100 schools that are administered well, 93 will have good achievements. Out of every 100 schools that are not having managed well, only one will have good levels of student achievement.

Accordingly, Whelan (2009) concludes that the students' achievements in school rarely surpass the leadership and management there. 
Hallinger \& Heck (1996: 14) determine that research regarding a principal's leadership has hardly any meaning if it does not relate to the school context. Leithwood, Jantzi \& Steinbach, (1999: 4) declare that excellent leadership is characterized by "superb sensitivity to contexts in which it functions". The place and the persons involved have immense influence on his actions and his behavior as a leader.

It is essential for the leaders to understand the context which they are leading. Most leaders are aware of the professional environmental very early. A new manager in new school, and a new context contribute to their intense distinction between this experience and another in a previous school. School leaders try to understand how matters are conducted. They analyze cultural and social alienation, the procedures and running the school.

Effective leaders have "contextual literacy" which includes understanding the type of school behavior and the reasons for it, and learning values on which it is based. Such literacy also requires such leaders to delve into the social and inter-personal dynamics in school - the organizational structure, history and politics. They have to get to know the role-holders and to understand the micro-politics inside and outside school. They also face issues connected to the level of school performance, strengths and weaknesses, and the opportunities to develop and learn that exist there. They must also take into account the economic factors and the character of the community that the school serves.

There are many factors that must be considered and understood: the type of school and ages it serves, its size, location, the procedures, personnel, administration - all these affect the school leadership and the order they afford the diverse actions. More than once I told our new principals that during the first months of their first position they face the greatest challenge in their professional lives as regards understanding issues.

The policy dictated by the local, regional or district administration has more direct influence than ever before on schools, since much authority is designated to them. The more authority designated, the greater the need for awareness by successful school principals to developments and special emphases in the field of special policy. Almost all the successful school principals draw on a shared pool of basic leadership methods (Leithwood et al., 2006). The implementation of these fundamental leadership methods and not the methods themselves - is context-sensitive. What distinguishes managers is not only their deeds but also their manner. Therefore there is no one correct way to manage school. Leaders need to act in ways that meet the needs of the school they head (NCSL, 2007: 5).

According to Leithwood \& Reihl (2003) and Leithwood et al. (2006) the educational leader has to:

1. Create a vision and establish directions, identify and formulate a vision, to create joint meaning and expectations of a high level of performance amongst members of the group, foster nurturing goals, and the ability for followup of the organization's performance.
2. Understand and develop people: The ability to provide intellectual stimulation and leadership through providing an example and establishing the skills that the teachers and the other members of the staff need to realize the school's goals of the school: open, guide, compensate.

3. Re-design the organization: Create cultures and processes based on the principal's cooperation to administer his environment and the work conditions; and all this while preserving the productive and sustainable relations with the parents and community, the school and the extended environment.

4. Managing the education system and the learning: Creating the productive work conditions for both the staff and the students, nurturing organizational stability for effective leadership that focuses on learning.

These core tasks also indicate that successful leadership necessitates certain characteristics. Leithwood et al. (2006) raise the possibility that much of the difference in effectiveness among leaders stems from a small number of personality attributes. In addition, the most successful school leaders are those with "an open mind" and willingness to learn from others. Their thought processes within the core values are more flexible than dogmatic, and they are more devoted to the objective (for example their expectations of high motivation amongst the staff, commitment, learning, achievements for all). They are also optimistic. Effective leadership creates motivation, and we expect the educational leader to be optimistic, good-natured, with a conscience and ethical, with a developmental orientation that enables improvement.

Besides the core missions and characteristics, we know that values are an inseparable part of leadership. As indicated in Flintham's (2003) work, the core values of the leaders are used for moral compass for their work. Work on moral purpose (Fullan, 2003), with moral and spiritual aspects of leadership (West-Burnham, 2002) and with leaders who are motivated by emotional heat (Flintham, 2009) clearly shows that the path they pave is led by values embedded in the vision every leader develops for his school.

Teaching and learning are the main objectives in schools. Therefore, leadership for teaching and learning is of crucial importance.

The McKinsey report of education systems with a high level of performance confirms the need for focus on these facets. The conclusions of that report are that systems with a high level of performance are different from other systems in that they focus in promoting high quality teaching throughout the system. The level of performance of any education system depends on the quality of the teachers (Whelan, 2009: 52). In other words, "quality of the education system cannot raise the level of the teachers", (Barber \& Mourshed, 2007:16). This statement can be translated, believes this author, as, the quality of the school is no higher than the quality of the teachers.

Most principals with whom I worked agree with this, and one may even add: the quality of the school is not more than the quality of its staff and administration. 
This means that both high quality teaching and quality leadership are essential to successful education. Thus one must consider their combined operation. My research and experience indicate that leadership strategically and effectively impact teaching, learning and class activity. Senior leaders determine a path and deal with strategic leadership of learning and teaching; middle level leaders (department heads, subject coordinators, year group coordinators etc) deal with operational leadership. The operational leaders are those who really affect what happens in classrooms.

Who is a leader? What is leadership? Definitions are abundant. Some claim there are 650 definitions, which is a clear sign of the lack of agreement and dissatisfaction.

In 1974 Stogdill concluded his comprehensive research saying that four decades of research on leadership produced a baffling mass of findings, and that the endless accumulation of empirical material had not provided an understanding of leadership. Thirty-five years later another study appeared in the journal, American Psychologist, that there is no accepted definition, no dominant paradigms for the research of leadership, and there is little agreement over the best strategy for its development.

Another index of the principal's functioning is offered by Kelly, Thornton \& Doharty (2005) who distinguish between management flexibility, which is the principal's ability to adopt a broad range of management styles, adapted to the situations he handles, and management efficiency measure, which is correspondence between management style and the suitable situation. A situation is feasible where the principal has a broad repertoire of possible management styles (for he enjoys high flexibility), but he applies them in an unsuitable manner to the school situation. This may emanate from faulty or foreign considerations regarding the best solution. On the other hand, the principal may only have a limited number of management styles, but he adapts them optimally to the situation he encounters.

Classification of educational leadership according to management flexibility criteria:

Management flexibility can characterize many managers, and especially those in community schools. According to the first article that was written by Friedman back in 1995, principals should adapt the management style to the school's level of readiness as regards community matters. Such a principal has high leadership flexibility (Kelly, Thronton \& Doherty 2005). When preparedness amongst the staff and community is low he must adopt a main style of clarification and persuasion, avoid applying too much pressure on the staff while providing explanations for the benefits for the community school. When the community preparedness is moderate, the principal must adopt a sharing style to enable more mature factors among the teachers and members of the community to leave their mark on the school and community leaderships. When community preparedness is high, the principal should fashion himself a pattern of behavior of delegating authority to the staff. Thus, he is likely to strengthen the staff's desire to contri- bute of their time and willingness to the great effort for the school and community survival.

Leadership determination: As opposed to flexible administration, perfectionist principals (and not just autocratic principals) are liable to be fixated to the voice of their inner judgment, which prevents them from listening to any comments or feedback from the staff. The driving force that is anger, which bursts out when someone subordinate to them does not meet the standards they set. Basset calls them "bitter idealists".

Hoy \& Wallace present several dilemmas with which the principal must cope, and his solution influences the way he runs school. These authors classify the findings into two main categories - outward management dilemmas and inward management dilemmas.

Table 1. $x x$

\begin{tabular}{|c|c|}
\hline Looking inwards & Looking outwards \\
\hline $\begin{array}{l}\text { Institutional goals compared } \\
\text { to individual needs } \\
\text { and interests. }\end{array}$ & $\begin{array}{l}\text { Consistency and organizationa } \\
\text { action versus changing externa } \\
\text { environment. }\end{array}$ \\
\hline $\begin{array}{l}\text { Formal management } \\
\text { methods, as opposed } \\
\text { to progress using the } \\
\text { informal approach }\end{array}$ & $\begin{array}{l}\text { Fixed administration } \\
\text { versus parents and outside } \\
\text { factors according to the } \\
\text { school objectives } \\
\text { vis-à-vis school objectives } \\
\text { and demands of the } \\
\text { outside environment. }\end{array}$ \\
\hline $\begin{array}{l}\text { Bureaucratic mastery } \\
\text { of subordinates } \\
\text { compared to autonomy } \\
\text { and self-jurisdiction. }\end{array}$ & $\begin{array}{l}\text { Activities designed to } \\
\text { strengthen internal factors to } \\
\text { improve school constructs } \\
\text { and methods versus relying } \\
\text { on outside professional } \\
\text { factors external to do so. }\end{array}$ \\
\hline $\begin{array}{l}\text { Centralizing control } \\
\text { in decision-making } \\
\text { compared to its } \\
\text { dissemination amongst } \\
\text { the administration } \\
\text { and lead teachers. }\end{array}$ & \\
\hline
\end{tabular}

P.sefie ,PhD can', (2012).

Two conclusions arise. Almost every management style entails costs as well as benefits, since some of them are closely connected to the principal's style. It is difficult to assess to what extent the principal can alter his style, even when reality he encounters in school dictates this.

\section{Conclusions}

Schools of the $21^{\text {st }}$ century develop leaders for the next century and hence should "increase speed" in all senses, as proposed by West-Burnham (2009: 101), "from improvement to transformation". Leadership will not change if our approach will be random and unstable; we need a planned, gradual and cohesive approach of school leaders of today and tomorrow, who have professional knowledge, skills, professional and political acumen, distinction and analyti- 
cal ability, as well as sensitivity.

In my opinion, the current trends in school leadership present individuals with greater demands than ever. They also require from the school leadership - educators, trainers, instructors, and policy makers - to ensure that leaders will learn and support the ways to realize this ability.

\section{References}

[1] Barber, M. \& Mourshed, M. (2007). How the world's bestperforming.

[2] Barber, M. \& Mourshed, M. (2007). How the world's bestperforming school systems come out on top. London: McKinsey.

[3] Barber, M., (2007). Instruction to deliver, London: Politicos Publishing.

[4] Ben Zvi, H. 2003 "Transformational leadership modelLeadership for Change and the top management people - a man" Hed Hagan 67 (2): pp. 4-9.

[5] Carmi, M. (2004). From teachers to chemistry leaders. The Chemistry, April. Weizmann Institute.

[6] Day, C. \& Leithwood, K. (Eds.) (2007). Successful principal leadership in times of change: An international perspective. London: Springer.

[7] Flintham, A.J. (2003) Reservoirs of hope: spiritual and moral leadership in head teachers. National College for School Leadership Practitioner Enquiry Report, Nottingham: NCSL.

[8] Flintham, A.J. (2009). Reservoirs of hope: Sustaining passion in leadership. In Davies \& Brighouse (Eds.) Passionate leadership in education. London: Sage.

[9] Fullan, M. (2003). The moral imperative of school leader- ship. Thousand Oaks, CA,: Corwin Press.

[10] Hallinger, P., \& Heck, R. (1996). Reassessing the principal's role in school effectiveness: a review of empirical research 1980-1995. Educational Administration Quarterly, 32[1]:544.

[11] Kelley, R. C., Thornton, B., \& Daugherty, R. (2005). Relationships between measures of leadership and school climate. Education, 126, 17-25. (ERIC Document Reproduction Service No. EJ725153) Retrieved September 24, 2006, from ERIC database.

[12] Leithwood, K., Day, C., Sammons, P., Harris, A., \& Hopkins, D., (2006). Seven strong claims about successful school leadership. Nottingham, NCSL \& DfES.

[13] Leithwood, K., Jantzi, D., \& Steinbach, R. (1999). Changing leadership for changing times. Buckingham: Open University Press.

[14] Leithwood, R. \& Reihl, C., (2003). What we know about successful school leadership. Philadelphia, PA, Laboratory for Student Success, Temple University; also published by NCSL.

[15] Mulford, B. (2008). The leadership challenge: Improving learning in schools. Camberwell, Vic.: Australian Council for Educational Research.

[16] NCSL, (2007). What we know about school leadership. Nottingham: NCSL, www.ncsl.org.uk.

[17] Peleg, S. (2012). "Leadership in education". PhD thesis research, Universities of Baber-Bolyai,Cluj Napoca, Romania.

[18] West-Burnham, J. (2002). Leadership and spirituality, NCSL Leading Edge Seminar Think-piece www.ncsl.org.uk /leadingedge.

[19] Whelan, F. (2009). Lessons learned: How good policies produce better schools. London: Whelan. 